\title{
Effects of Wastewater Treatment Plant Effluent in a Receiving Stream on Reproductive Behavior of Fathead Minnows (Pimephales promelas)
}

\author{
Joseph M. Leese (D), Julia McMahon and Joseph C. Colosi * \\ Department of Biology, DeSales University, Center Valley, PA 18034, USA; joseph.leese@desales.edu (J.M.L.); \\ jmcmcmahon323@gmail.com (J.M.) \\ * Correspondence: joseph.colosi@desales.edu
}

check for

updates

Citation: Leese, J.M.; McMahon, J.; Colosi, J.C. Effects of Wastewater Treatment Plant Effluent in a Receiving Stream on Reproductive Behavior of Fathead Minnows (Pimephales promelas). Fishes 2021, 6, 14. https://doi.org/10.3390/ fishes 6020014

Academic Editor: Maria Angeles Esteban

Received: 15 March 2021

Accepted: 9 April 2021

Published: 12 April 2021

Publisher's Note: MDPI stays neutral with regard to jurisdictional claims in published maps and institutional affiliations.

Copyright: (c) 2021 by the authors. Licensee MDPI, Basel, Switzerland. This article is an open access article distributed under the terms and conditions of the Creative Commons Attribution (CC BY) license (https:// creativecommons.org/licenses/by/ $4.0 /)$.

\begin{abstract}
Wastewater treatment plant effluents contain a variety of endocrine disrupting chemicals (EDCs), including chemicals with estrogenic activity such as $17 \beta$-estradiol (E2), $17 \alpha$-ethinyl estradiol (EE2), and nonylphenols. These substances can affect both behavior and physiology in vertebrate animals. To explore the presence and effects of these EDCs in a natural setting, juvenile and adult male fathead minnows, Pimephales promelas, were held in cages upstream and downstream of the effluent site of a wastewater treatment plant for 21 days and subsequently tested for changes in reproductive behaviors and production of vitellogenin. Additionally, estrogenic activity in the stream was measured using a yeast bioassay. Estrogenicity was found to be significantly higher downstream of the wastewater effluent when compared to levels upstream. Vitellogenin levels did not show a correlational pattern with levels of estrogenicity in the water, but two measures of reproductive behaviors occurred significantly less often in downstream males than upstream males. This suggests that a brief (three-week) exposure to stream water containing wastewater treatment plant effluent can bring about changes in reproductive behavior of fish and that behavior may be more sensitive to low levels of environmental endocrine disruptors than vitellogenin production.
\end{abstract}

Keywords: endocrine disruptor; environmental estrogens; Pimephales promelas; reproductive behavior; wastewater treatment plant effluent

\section{Introduction}

Over the past several decades, there has been growing concern over the potential health risks to humans and wildlife due to exposure to endocrine-disrupting chemicals (EDCs) in the environment [1,2]. Effluents of wastewater treatment plants (WWTPs) contain a variety of chemicals such as surfactants, pesticides, industrial materials, the human estrogens estrone (E1), 17 $\beta$-estradiol (E2), and estriol (E3), and the pharmaceutical estrogen ethinylestradiol (EE2), also known as the birth control hormone, which possess estrogenic activity [3]. To date, there are more than 50 chemicals from industrial, municipal, and agricultural sources that are known to interfere with endocrine systems of wildlife [4-6].

These EDCs in the environment can have profound effects on both the physiology and behavior of wildlife and humans [1,7]. The most commonly studied negative effects of EDCs are on sex determination, onset of sexual maturation, secondary sex characteristics, and sperm and egg production [8]. Endocrine disruption in rainbow trout (Oncorhynchus mykiss) was documented when researchers detected vitellogenin (VTG) in males exposed to WWTP effluent [9]. Vitellogenin is an egg yolk precursor protein normally only found in sexually mature females and is nondetectable in immature fish and mature male fish. Its production, however, is greatly stimulated by estrogenic compounds in water [9-11]. In addition to protein expression, changes in reproductive behavior can be caused by exposure to EDCs. Declines in male reproductive behavior and fitness were caused by exposure to EE2 in sand gobies [7] and zebra fish [12]. Martinović et al. [13] showed that male fathead 
minnows (Pimephales promelas) exposed to the effluent of a wastewater treatment plant displayed decreased agonistic behavior as well as less defined secondary sex characteristics, resulting in reduced reproductive fitness.

In the 1990s and early 2000s, most studies exploring the effects of EDCs focused exclusively on either physiological impacts (i.e., protein expression) or behavior (i.e., aggression, courtship, and/or nest building), and relatively few looked into these effects simultaneously in the same model system [14,15]. In more recent years, it has become commonplace to investigate both physiological and behavioral changes induced by endocrine disrupting chemicals. A study using the brackish medaka, Oryzias melastigma, found that both physiology and behavior were altered after fish were exposed to wastewater effluent brough into the laboratory [16]. Studies in fathead minnows, Pimephales promelas, have correlated changes in gene expression patterns, anatomy, behavior, and reproductive outputs in male and female fish exposed to varying levels of EDCs [13,17]. Studying changes in both physiology and behavior simultaneously provides a more comprehensive understanding of how EDCs can affect organisms and what the environmental relevance of these effects are. These studies, however, also have had limitations. Some focus on exposure to a specific compound or compounds [17]. Others expose animals directly to wastewater effluent, rather than the natural environment that the effluent is released into, often subjecting animals to higher concentrations than are truly found in the aquatic environment $[13,16]$.

Unlike previous studies that have investigated the effect of EDCs in WWTP effluent by bringing water samples into the lab, we exposed fish directly to the water in a receiving stream of a wastewater treatment plant. We placed juvenile and adult male fathead minnows in stream water above and below a WWTP effluent site. We assayed the levels of estrogenicity expressed as parts per trillion of $17 \beta$-estradiol equivalence at both locations weekly, measured VTG production in juvenile fish that should not be producing the protein and conducted behavioral experiments on adult males to assay reproductive behaviors. We hypothesized that downstream of the WWTP effluent, levels of estrogenicity would be higher, juveniles would have higher levels of VTG, and males would have altered reproductive behaviors when compared to individuals placed upstream.

\section{Results}

\subsection{Water Chemistry and Estrogenicity Assay}

Comparing the water quality measures across the effluent, upstream, and downstream collection sites revealed significant differences in temperature, conductivity, $\mathrm{pH}$, dissolved oxygen, and estrogenicity (Table 1). Specifically, the downstream and upstream sites where the fish were exposed differed significantly in conductivity, $\mathrm{pH}$, and estrogenicity, but did not differ in temperature or dissolved oxygen.

Table 1. Results of a one-way ANOVA $(\mathrm{df}=2)$ comparing water quality measures (mean $\pm \mathrm{SE})$ across the effluent, upstream, and downstream exposure sites. There were significant effects of source in all measures.

\begin{tabular}{cccccc}
\hline Variable & Effluent & Upstream & Downstream & F & $p$ \\
\hline Temperature $\left({ }^{\circ} \mathrm{C}\right)$ & $15.50 \pm 0.84$ & $8.60 \pm 1.07$ & $11.20 \pm 0.80$ & 14.605 & $<0.001$ \\
Conductivity $(\mu \mathrm{S} / \mathrm{cm})$ & $706.85 \pm 8.33$ & $433.00 \pm 4.90$ & $536.71 \pm 10.09$ & 293.741 & $<0.001$ \\
$\mathrm{pH}$ & $7.11 \pm 0.06$ & $7.89 \pm 0.09$ & $7.56 \pm 0.10$ & 22.954 & $<0.001$ \\
Dissolved oxygen $(\mathrm{mg} / \mathrm{L})$ & $8.81 \pm 0.50$ & $11.24 \pm 0.53$ & $11.07 \pm 0.34$ & 8.553 & 0.002 \\
Estrogenicity $(\mathrm{ppt})$ & $11.29 \pm 2.13$ & $2.89 \pm 1.10$ & $7.99 \pm 1.74$ & 6.109 & 0.009 \\
\hline
\end{tabular}

Temperature was nearly significantly different between upstream and downstream water (LSD post-hoc test; $p=0.059$ ), but was significantly higher in the wastewater effluent than both upstream and downstream sites ( $p<0.001$ and $p=0.004$, respectively; Figure 1A). Conductivity was significantly different in all three pair-wise comparisons (effluent vs. upstream, $p<0.001$; effluent vs. downstream, $p<0.001$; upstream vs. downstream, $p<0.001$; Figure 1B). The same pattern occurred for $\mathrm{pH}$ (effluent vs. upstream, $p<0.001$; effluent 
vs. downstream, $p=0.001$; upstream vs. downstream, $p=0.011$; Figure $1 \mathrm{C}$ ). The dissolved oxygen of the upstream and downstream water was consistently high (no measured value below $9.4 \mathrm{mg} / \mathrm{L}$ ) for even the most sensitive fish such as trout and did not differ between stream sites $(p=0.80)$, but was significantly lower in the effluent than both stream sites (effluent vs. upstream, $p=0.002$; effluent vs. downstream, $p=0.003$; Figure 1D). The estrogenicity of the effluent and downstream water was consistently higher than that of the upstream water, and this was confirmed with post-hoc pairwise comparisons (effluent vs. upstream, $p=0.003$; downstream vs. upstream, 0.049; Figure 2).

(A)

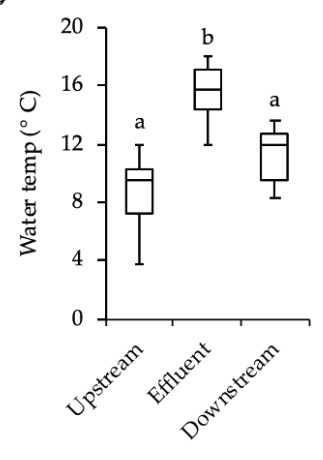

(C)

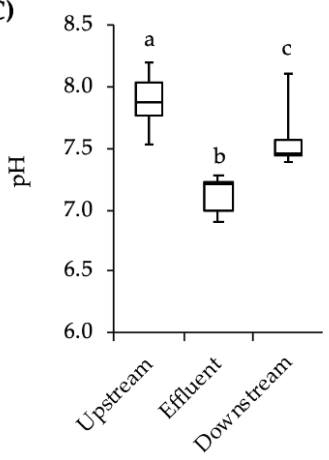

(B)

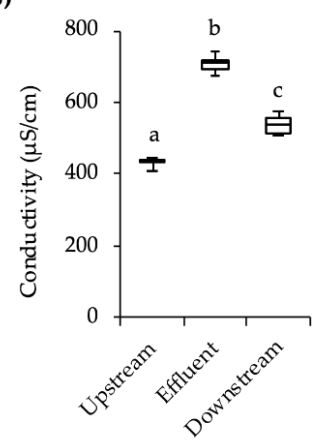

(D)

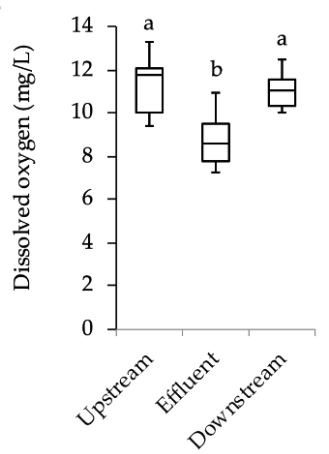

Figure 1. Water quality measures taken weekly during the field exposure. The midline of the box is the median, the boxes above and below the median contain $25 \%$ of values above and below the median, respectively. Whiskers indicate maximum and minimum values. Lower case letters $(a, b, c)$ indicate statistical significance between groups. (A) Temperature $\left({ }^{\circ} \mathrm{C}\right)$ was significantly different in the effluent than the upstream and downstream waters. (B) Conductivity $(\mu \mathrm{S} / \mathrm{cm})$ was significantly different across all three water sources. (C) $\mathrm{pH}$ was significantly different across all three water sources. (D) Dissolved oxygen was significantly lower in the effluent compared to upstream and downstream sites, but upstream and downstream water did not differ.

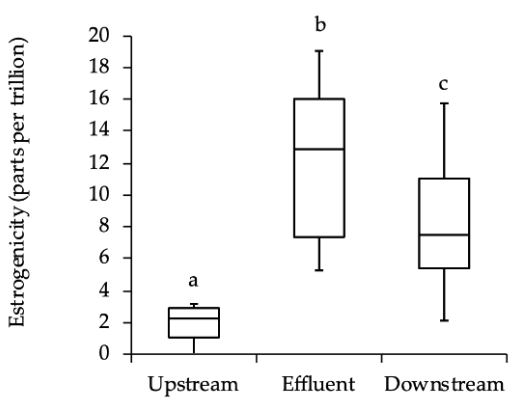

Figure 2. Estrogenicity (17 $\beta$-estradiol equivalent in parts per trillion) of upstream, effluent, and downstream water samples. Lower case letters $(a, b, c)$ indicate statistical significance between groups. Mean downstream estrogenicity was greater than mean upstream estrogenicity by 5.1 parts per trillion $17 \beta$-estradiol equivalent, a $176 \%$ increase. 


\subsection{Vitellogenin Assay}

The mean vitellogenin/g of fish for upstream and downstream fish were $298 \mathrm{ng}$ and $4190 \mathrm{ng}$, respectively, but these values were not significantly different ( $p=0.37$; Figure 3). This was largely the result of tremendous variation in individual levels of VTG, ranging from $0 \mathrm{ng} / \mathrm{g}$ to $23,800 \mathrm{ng} / \mathrm{g}$ in downstream fish and $1 \mathrm{ng} / \mathrm{g}$ to $940 \mathrm{ng} / \mathrm{g}$ in upstream fish. The two highest concentrations of vitellogenin per gram of fish were in the downstream samples; however, the lowest concentrations were also in the downstream samples. Two of the upstream samples had 1 and $2 \mathrm{ng} / \mathrm{g}$ of fish and two of the down steam samples had $0 \mathrm{ng} / \mathrm{g}$ of vitellogenin.

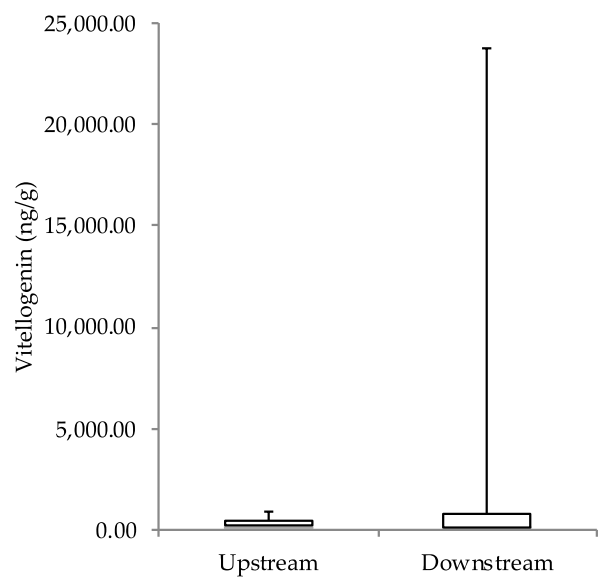

Figure 3. Vitellogenin (ng/g) in upstream $(n=6)$ and downstream $(n=6)$ fish. Mean upstream vitellogenin was $298 \mathrm{ng} / \mathrm{g}$, which was only $7.1 \%$ of the average downstream value of $4190 \mathrm{ng} / \mathrm{g}$ but the difference was not statistically significant $(p=0.37)$.

\subsection{Behavior Assay}

After behavioral trials were scored using the ethogram described in Table 2, three behaviors (tail-beating, leading, and quivering) only occurred in one or two trials and were omitted from analysis. Regarding the other behaviors, in comparing experimental and control males, there were no significant differences between upstream males and control males that had never been placed in stream water in male-directed behaviors (butting and biting behavior: $Z=-1.75, p=0.08$; chasing: $Z=-0.11, p=0.92$; Figure $4 \mathrm{~A}$ ), femaledirected behaviors (butting and biting: $Z=-0.14, p=0.89$; chasing: $Z=-0.17, p=0.87$; Figure $5 \mathrm{~A}$ ), or nest-directed behaviors (nibbling, $Z=-1.60, p=0.11$, and burrowing, $\mathrm{Z}=-0.54, p=0.59$; Figure $6 \mathrm{~A})$.

Table 2. Ethogram used to analyze behavior of control and experimental fathead minnows (exposed to stream water); modified from Martinović et al. [13].

\begin{tabular}{|c|c|}
\hline Behavior & Description \\
\hline \multicolumn{2}{|l|}{ Male to male } \\
\hline Butting/biting & Intentionally and forcefully swimming into or biting the other male \\
\hline Chasing & Swimming toward and/or chasing the other male \\
\hline Tail beating & Swimming next to the other male and undulating his body so as to contact his tail with the other male \\
\hline \multicolumn{2}{|l|}{ Male to female } \\
\hline Butting/biting & Intentionally and forcefully swimming into or biting the female \\
\hline Chasing & Swimming toward and/or chasing the female \\
\hline Tail beating & Swimming next to the female and undulating his body so as to contact his tail with the female \\
\hline Leading & Rapidly swimming from the mouth of the nest to the female and back to the nest \\
\hline Quivering & Rapidly vibrating the body \\
\hline \multicolumn{2}{|l|}{ Male to nest } \\
\hline Nibbling & Male inside of the nest and generating contact between the mouth and ceiling or floor of the nest \\
\hline Burrowing/rubbing & Male rubbing along the outside of the nest or digging under the side of the nest \\
\hline
\end{tabular}


(A)

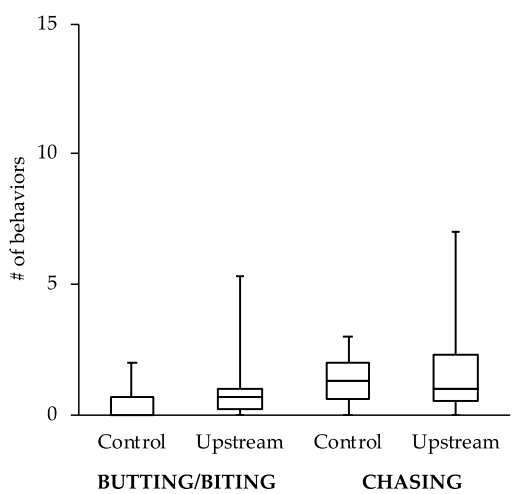

(B)

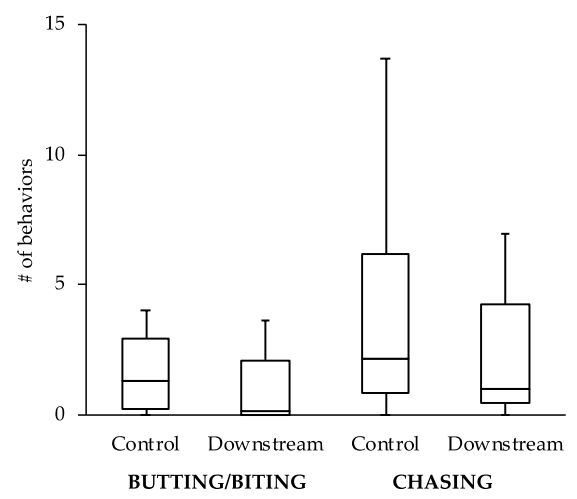

Figure 4. Frequencies of male-directed behaviors (butting/biting and chasing) of experimental (exposed to stream) and control (not exposed to stream) males. (A) There were no significant differences between experimental males placed upstream and control males. (B) Males placed downstream showed significantly less butting/biting behavior than control males.
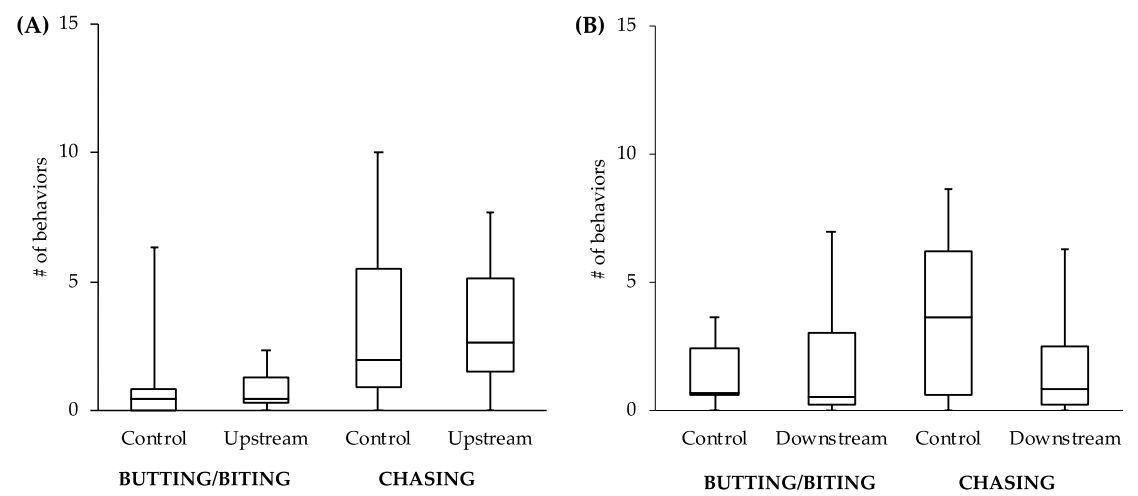

Figure 5. Frequencies of female-directed behaviors (butting/biting and chasing) of experimental (exposed to stream) and control (not exposed to stream) males. There were no significant differences between experimental males placed upstream (A) or downstream (B) and control males.
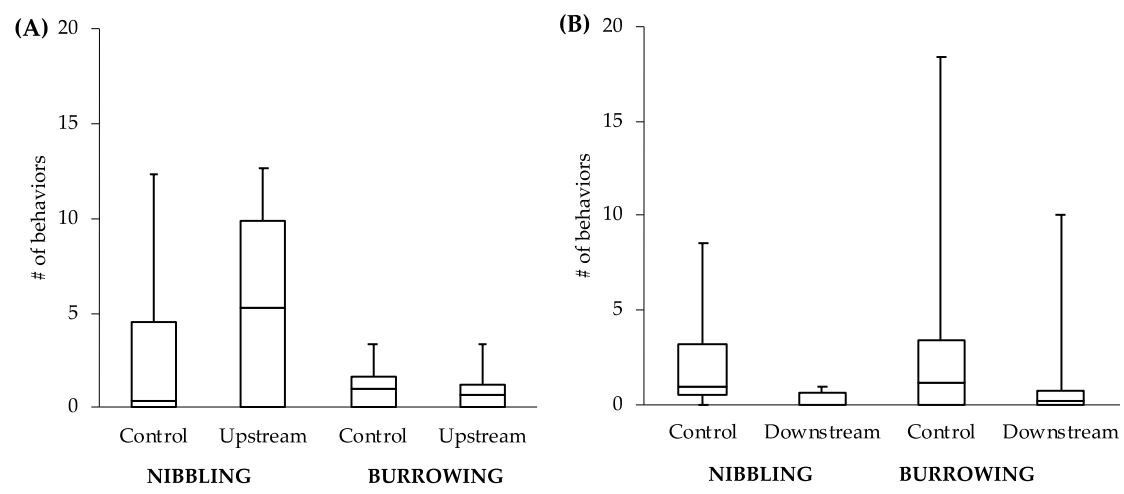

Figure 6. Frequencies of nest-directed behaviors (nibbling and burrowing) of experimental (exposed to stream) and control (not exposed to stream) males. There were no significant differences between experimental males placed upstream (A) and control males, but males placed downstream (B) showed significantly less nibbling behavior than control males.

When comparing downstream males with control males, we found that there was significantly less male-directed butting/biting $(Z=-2.214 ; p=0.027)$, but no differences in male-directed chasing $(Z=-0.34 ; p=0.74$; Figure $4 \mathrm{~B})$. There were also no differences in female-directed behaviors (butting and biting: $Z=-0.41, p=0.69$; chasing: $Z=-1.57$, 
$p=0.12$; Figure 5B). There was, however, a significant difference in the number of nest nibbling behaviors, with control males showing more nibbling behavior than downstream males $(Z=-2.207, p=0.027$; Figure $6 B)$, but no difference in burrowing $(Z=-0.52, p=0.60$; Figure $6 \mathrm{~B})$.

\section{Discussion}

We hypothesized that the estrogenicity of stream water downstream of a WWTP effluent would be greater than that of water upstream, and furthermore, that fish exposed to this increase in estrogenicity would demonstrate physiological (VTG production) and behavioral effects. We indeed found differences in estrogenicity that correlated with changes in some behaviors, but we found no evidence of differences in VTG production. The estrogen yeast assay results demonstrate that the estrogenic activity of the effluent is significantly higher than the upstream water. Not surprisingly, the release of the SSTP effluent causes an increase in the estrogenicity of the downstream water, with levels of estrogenicity approximately $175 \%$ higher than the upstream environment. This difference suggests that any differences in reproductive behavior between fish above and below the effluent site may be due to exposure to different levels of estrogenicity in the water.

However, other variables must also be considered. The temperature and conductivity downstream of the effluent site were slightly higher than the values upstream of the effluent site and the $\mathrm{pH}$ downstream was slightly lower. There was also more debris covering the downstream cages at the end of the three-week exposures. There could have been other differences in upstream and downstream water conditions such as the speed of the current, the levels of nutrients, and the depth of the water. Additionally, apart from the chemicals with estrogenic activity, there are hundreds of pharmaceutical and personal care compounds as well as cleaning agents, fire retardants, and anti-stick chemicals in domestic wastewater that the fish may have been exposed to, but which were not monitored in this study [18-20]. Little is known about the biological effects of most of these chemicals on fish either singly or in combination and they may have also affected the fish. There is no way to explicitly determine that one or more of these factors did not play a role in changing the behavior of males exposed to the downstream site, but the fact that estrogenicity was significantly different at least supports the hypothesis that it played a role in any noticeable effects.

Unexpectedly, the vitellogenin results of full body homogenates were inconclusive, and did not form any specific pattern. In general, without exposure to estrogenic compounds, male juvenile fathead minnows have much lower levels of vitellogenin than do juvenile females-approximately $30 \mathrm{ng} / \mathrm{mL}$ of plasma in males compared to $4000 \mathrm{ng} / \mathrm{mL}$ for females [21]. This level increases dramatically (over 100 $\times$ ) in juveniles in the lab after exposure to $17 \beta$-estradiol [21]. In our study, only three fish had vitellogenin concentrations greater than $1000 \mathrm{ng} / \mathrm{g}$ of fish. While these fish were in the downstream treatment group, the majority of fish in both treatments had levels of vitellogenin expected in fish unexposed to estrogenicity. This finding could in part be due to our low sample size, as well as the many challenges and limitations involved with measuring vitellogenin using enzyme immunoassays [22]. Additionally, the complexity of the estrogen receptor complex with its multiple subtypes in teleost fish makes drawing a direct line between estrogen-like compounds in the environment and vitellogenin production problematic [23]. However, at the time of the completion of this study, vitellogenin assays were one of the most common methods for detecting levels of concern of environmental estrogens, and they continue to be widely used today, despite legitimate concerns about the accuracy and usefulness of the process [22].

It is worth noting that while we did not detect significant differences between upstream and downstream fish in vitellogenin, we did find slight behavioral differences. If we had not completed a behavioral assay and focused exclusively on vitellogenin, our conclusion would be that the difference in levels of estrogenicity upstream and downstream of the WWTP effluent was not enough to produce this commonly studied effect. While 
unpredicted, our results are not entirely unique as Soffker and Tyler [15] cite multiple studies where behavioral effects were observed but physiological effects were not found. Our assay revealed some slight but significant differences in behavior. In relation to controls, two of the reproductive behaviors of downstream males, (male-directed butting/biting and nest nibbling) were found to occur significantly less often than those same behaviors in the upstream males. Similar results were detected for fathead minnows in other studies $[3,17,24]$ and in three-spined sticklebacks (Gasterosteus aculeatus) [25] and zebrafish (Danio rerio) [12,26], but, unlike our study, these studies used higher concentrations of $17 \beta-$ estradiol equivalent than is normally found in the aquatic environment [15]. Male-directed butting/biting is an aggressive behavior commonly used in territorial disputes that is likely to impact a male's ability to secure a territory. On the other hand, nest-nibbling is a behavior used by males in preparing a nest site for egg deposition from females. Males showing lower levels of this behavior are likely not preparing for reproduction. A decrease in either of these types of behavior should have direct fitness consequences.

While the comparisons between other behaviors did not reveal statistically significant differences, the general patterns of the data follow what would be expected of estrogenic influence. For example, the male-to-male behavior of control fish in the tanks with the upstream males was similar to that level of behavior of the upstream males themselves (Figure 4A). However, the level of male-to-male behavior of the control fish in the tanks with the downstream males (Figure 4B) more closely resembled the levels of male-to-female behavior of the controls in tanks with both upstream and downstream males (Figure 5). This intriguing pattern suggests that not only might the behavior of downstream males be influenced by exposure to EDCs, but also that the response of conspecifics toward these males could be affected. As social interactions between males are important for securing nest sites and attracting females, the response of others in the population to individuals that have been exposed to EDCs could have more dramatic effects on fitness than any change in behavior of the individuals themselves.

Although only two behaviors examined did reveal significant differences in the downstream males, we feel this study likely underestimates the influence of estrogen on reproductive behavior in this system due to the small sample size and relatively short exposure time. The fact that any significant differences were found in such a conservative study suggests that estrogenicity at this site may have a very powerful effect on reproductive behaviors. This finding, coupled with the lack of results in the vitellogenin assay, may very well mean that environmental estrogens are having a much greater effect on wildlife more generally than previously thought.

\section{Materials and Methods}

\subsection{Test Fish and Study Site}

Adult fathead minnows ( $n=32)$ to be used in the behavioral assay (approximately five months old; mean standard length $(\mathrm{SL})=5.03 \mathrm{~cm}$; mass $=3.20 \mathrm{~g}$ ) were acquired from Aquatic Bio Systems in Fort Collins, Colorado. Males were identified as sexually mature by the presence of tubercles on their heads and spongy dorsal pads. Juvenile minnows of similar size $(n=80$; mean $\mathrm{SL}=5.45 \mathrm{~cm}$; mass $=2.15 \mathrm{~g})$, but lacking tubercles and dorsal pads, were bought from Chris's Bait and Tackle, in Mertztown, PA. Juvenile fish were used for the vitellogenin assay only. Field sites were located $10 \mathrm{~m}$ upstream and $10 \mathrm{~m}$ downstream of the wastewater treatment effluent of the Upper Saucon Township's Wastewater Treatment Plant in Lehigh County, PA ( $40^{\circ} 33^{\prime} \mathrm{N}, 75^{\circ} 23^{\prime} \mathrm{W}, 113 \mathrm{~m}$ elevation). Based on data in [27], the drainage area of the Saucon Creek watershed upstream of the Upper Saucon Township Wastewater Treatment plant is about $50 \mathrm{~km}^{2}$; land use is approximately $30 \%$ agriculture, $30 \%$ suburban, $20 \%$ forested, and $10 \%$ a variety of other land uses. The average daily discharge by the Upper Saucon Township Wastewater Treatment plant is $53 \mathrm{~L} / \mathrm{s}$ and the average flow of the Saucon Creek is $1700 \mathrm{~L} / \mathrm{s}$ [28]; personal communication by Karl E. Schreiter of Schreiter Engineering Associates]. The collection system is comprised of approximately 96 miles of underground pipe ranging from 8 inches to 30 inches in diameter 
and there are approximately 7000 customers [28]. The wastewater treated at the plant is approximately $90 \%$ domestic waste. The plant uses aerobic activated sludge for the digestion of organic matter and the water passes through banks of UV lights for sanitation before discharge to the creek (personal communication; John Guinet, Assistant Director Water and Sewer Resources Upper Saucon Township). The study occurred between October and November 2013. All animal subjects were treated in accordance to guidelines set out by the National Research Council and the Guide for the Care and Use of Laboratory Animals.

\subsection{Experimental Design}

For exposure to stream water, fish were placed in wire cages made from $3.3 \mathrm{~mm}$ mesh galvanized wire hardware cloth $(\mathrm{d} \times 1=22 \mathrm{~cm} \times 56 \mathrm{~cm})$. The upstream end of the cage was covered by an 11 L black plastic bucket, which provided protection from the stream current. To prevent movement and maintain the cages in the water column, each wire mesh cage had a cement block attached to it by a metal cable. On the day fish were to be put in the stream, 16 adult male minnows and approximately 40 juveniles were moved from laboratory holding tanks to 2-L flasks of stream water that had been previously collected and allowed to warm to room temperature. The flasks were then placed in a $4{ }^{\circ} \mathrm{C}$ refrigerator for approximately $2 \mathrm{~h}$ to allow the fish to acclimate by gradually lowering the temperature of the water. The flasks were transported to the field site in coolers and, upon arrival, placed in the stream for approximately $30 \mathrm{~min}$ for further temperature acclimation. Fish were placed into two cages positioned approximately $10 \mathrm{~m}$ downstream from the effluent site, and two cages positioned $10 \mathrm{~m}$ upstream (4 adults and 10 juveniles per cage). The first group of fish was placed in the stream on 28 October 2013. After 21 days the fish were retrieved and returned to the lab in 2-L flasks in a cooler for analysis. A second group of fish was placed in the stream in the same way on 11 November 2013 and retrieved after 21 days. Due to low survival rates in the cages ( $\sim 50$ of adults, $\sim 20 \%$ of juveniles), individuals from both exposures were pooled into a single analysis for behavior and vitellogenin. While fish were being exposed to stream water, temperature, $\mathrm{pH}$, conductivity, and dissolved oxygen levels were measured weekly with hand-held meters in the vicinity of the cages. The meters were calibrated each measurement day.

\subsection{Estrogenicity Assay}

For assaying levels of estrogenicity in the water, samples were obtained and filtered on site through a $0.2 \mu \mathrm{m}$ sterile bacteriological filter and kept on ice during transport back to the lab. One upstream, one downstream, and one effluent sample of $100 \mathrm{~mL}$ each was collected approximately weekly from 28 October 2013 until 2 December 2013 for a total of 7 samples from each source. Estrogenic activity was measured using the YESne, a yeast estrogen assay developed by Colosi and Kney [29] as a modification of the YES bioassay [18]. In brief, $0.5 \mathrm{~mL}$ of stream water was added to $1.5 \mathrm{~mL}$ microfuge tubes. Either a spike of $1.56 \times 10^{-8} \mathrm{M} 17 \beta$-estradiol in $10 \mu \mathrm{L}$ of dimethyl sulfoxide (DMSO) or $10 \mu \mathrm{L}$ of DMSO alone was added to each tube. Yeast $(1 \mu \mathrm{L}$, a 1 to 100 dilution of stock; OD620 $=1.2$ ) was added to each tube in $0.5 \mathrm{~mL} 2 \times$ medium. A set of standards with $17 \beta$-estradiol in concentrations ranging from 0 to $9.38 \mathrm{E}-11$ molar in $10 \mu \mathrm{L}$ of DMSO was included with each sample run. All samples and standard curve concentrations were run in triplicate. The tubes were incubated at $30{ }^{\circ} \mathrm{C}$ for $24 \mathrm{~h}$. After incubation, $100 \mu \mathrm{L}$ of the original mixture was added to $900 \mu \mathrm{L}$ of ortho-nitrophenyl- $\beta$-galactoside (ONPG) in Z-buffer (final concentration of ONPG was $0.36 \mathrm{mg} / \mathrm{mL}$ ) in a new tube and incubated at $37^{\circ} \mathrm{C}$ for $60 \mathrm{~min}$. In the first incubation, the yeast produced the enzyme $\beta$-galactosidase in proportion to the estrogenicity in the water. In the second incubation, the $\beta$-galactosidase cleaved the ONPG producing the yellow ortho-nitrophenol. A $400 \mu \mathrm{L}$ of stop buffer (1 M $\mathrm{Na}_{2} \mathrm{CO}_{3}$ ) was added to each tube, and $200 \mu \mathrm{L}$ of the solution was transferred to a microtiter plate, which was read at $414 \mathrm{~nm}$. 


\subsection{Vitellogenin Assay}

Juveniles were euthanized using tricaine methanesulfonate (MS222) at concentrations greater than $250 \mathrm{mg} / \mathrm{L}$ after retrieval from the exposure site. The fish were then weighed and stored at $-20^{\circ} \mathrm{C}$. Following the procedure described in "Preparation of whole-body homogenates from small fish using a hand-held homogenizer" (Biosense Laboratories AS, Bergen, Norway, 2004.1), ice cold sample buffer (PBS, 1\% BSA with 3-7 TIU Aprotinin/mg) and fish were placed into a homogenizer at a 1:2, weight to volume ratio. The samples were homogenized until the tissue was finely processed, and then placed into labeled tubes on ice. The samples were centrifuged at $4{ }^{\circ} \mathrm{C}, 20,000 \times g$ for $30 \mathrm{~min}$. Then, keeping the tubes on ice, the supernatant was carefully collected to avoid any fat in the sample. The homogenate samples were stored at $-80^{\circ} \mathrm{C}$.

Vitellogenin was assessed for all but the smallest 2 of the 14 juvenile fish that survived both sets of the three-week exposure in the creek with a vitellogenin assay kit (Biosense Laboratories, Bergen, Norway). The kit contained pre-coated microplates, plate sealers, dilution buffer, PBS/ Tween tablets, detecting antibody, TMB substrate, and fathead minnow VTG standard, used to measure VTG in the plasma. Dilution series for each full body homogenate sample was established using the provided buffer at 1:25, 1:2500, and 1:250,000 dilutions. The standard curve included 11 dilution steps with a final concentration of $0.05 \mathrm{ng}$ VTG $/ \mathrm{mL}$. In duplicate, $100 \mu \mathrm{L}$ of each VTG standard dilution and each sample dilution was added to the appropriate wells. The plate was sealed, incubated at room temperature for $90 \mathrm{~min}$, and then washed $3 \times$ with $300 \mu \mathrm{L}$ washing buffer per well. The detecting antibody was diluted 1:500 and $100 \mu \mathrm{L}$ was added to all wells. The plate was sealed, incubated at room temperature for $30 \mathrm{~min}$, then washed $5 \times$ with $300 \mu \mathrm{L}$ of washing buffer per well before adding $100 \mu \mathrm{L}$ of TMB substrate to each well. The plate was left to incubate in the dark at room temperature for $20 \mathrm{~min}$. The reaction was stopped by adding $100 \mu \mathrm{L} 0.3 \mathrm{M} \mathrm{H}_{2} \mathrm{SO}_{4}$ to each well and then the plate was read in a microplate reader at $450 \mathrm{~nm}$.

\subsection{Behavior Assay}

After retrieval from the field site, adult male fathead minnows $(n=15)$ were assayed for reproductive behavior in experimental tanks in a controlled laboratory setting (temperature $=22 \pm 2{ }^{\circ} \mathrm{C} ; 12: 12$ light:dark). Prior to testing, each male had a small clip taken from the bottom tailfin for identification purposes and was then placed in separate $37 \mathrm{~L}$ experimental aquaria. An equal number of control males that were not exposed to stream water had the upper tail fin clipped before being added to each experimental aquarium. Finally, a sexually mature female was placed in each tank along with two potential nest sites (terra cotta flower pots). Approximately half of the experimental males came from cages placed upstream of the wastewater treatment plant outflow $(n=7)$ and the other males came from cages placed downstream $(n=8)$. After a 24 -h acclimation period, each tank was video-recorded $10 \mathrm{~min} /$ day for 3 consecutive days. Observers were not present in the room during the recording of behavior.

Observers blind to treatment groups analyzed video recordings for 10 behaviors in 3 categories: (1) Male to male (butting/biting, chasing, and tail beating), (2) male to female (butting/biting, chasing, tail beating, leading, and quivering), and (3) male to nest (nibbling and burrowing/rubbing). An ethogram was modified from Martinović et al. [13] after preliminary observations of minnows prior to the start of the study (Table 2). The number of behaviors per observation was averaged across the three days for both control and experimental males in the aquarium.

\subsection{Statistical Analysis}

Environmental parameters of stream water (temperature, $\mathrm{pH}$, conductivity, dissolved $\mathrm{O}_{2}$, and estrogenicity) were compared between effluent, upstream, and downstream sites at each sampling date using a one-way ANOVA with Fishers LSD post-hoc tests. Levels of VTG were compared between downstream and upstream fish using an independent samples t-test. For the behavior assay, the number of behaviors was not normally distributed, so 
a non-parametric Wilcoxon Signed Ranks test was used to compare the behavior between control and experimental males in both upstream and downstream conditions. Statistical analyses were conducted using SPSS 17.0 and alpha was set at $p=0.05$.

Author Contributions: Conceptualization, J.C.C., J.M., and J.M.L.; methodology, J.C.C. and J.M.L.; formal analysis, J.C.C. and J.M.L.; investigation, J.C.C. and J.M.; data curation, J.C.C. and J.M.L.; writing-original draft preparation, J.C.C., J.M., and J.M.L.; writing-review and editing, J.C.C. and J.M.L.; All authors have read and agreed to the published version of the manuscript.

Funding: This research received no external funding.

Acknowledgments: We thank Savanna Risser and Alexa Dunlap for assistance in collecting behavioral data and the staff of the Upper Saucon Township water and sewer Department for their cooperation and assistance.

Conflicts of Interest: The authors declare no conflict of interest.Animal Welfare Statement: All animal subjects were treated in accordance with guidelines set out by the National Research Council and the Guide for the Care and Use of Laboratory Animals.

\section{References}

1. Tyler, C.R.; Jobling, S. Roach, Sex, and Gender-Bending Chemicals: The Feminization of Wild Fish in English Rivers. Bioscience 2008, 58, 1051-1059. [CrossRef]

2. Tijani, J.O.; Fatoba, O.O.; Petrik, L.F. A Review of Pharmaceuticals and Endocrine-Disrupting Compounds: Sources, Effects, Removal, and Detections. Water Air Soil Pollut. 2013, 224, 1-29. [CrossRef]

3. Garcia-Reyero, N.; Lavelle, C.M.; Escalon, B.L.; Martinović, D.; Kroll, K.J.; Sorensen, P.W.; Denslow, N.D.; Martinovic-Weigelt, D. Behavioral and genomic impacts of a wastewater effluent on the fathead minnow. Aquat. Toxicol. 2011, 101, 38-48. [CrossRef]

4. Borgert, C.J.; LaKind, J.S.; Witorsch, R.J. A critical review of methods for comparing estrogenic activity of endogenous and exogenous chemicals in human milk and infant formula. Environ. Health Perspect. 2003, 111, 1020-1036. [CrossRef] [PubMed]

5. Falconer, I.R.; Chapman, H.F.; Moore, M.R.; Ranmuthugala, G. Endocrine-disrupting compounds: A review of their challenge to sustainable and safe water supply and water reuse. Environ. Toxicol. 2006, 21, 181-191. [CrossRef]

6. Sonnenschein, C.; Soto, A.M. An updated review of environmental estrogen and androgen mimics and antagonists. J. Steroid Biochem. Mol. Biol. 1998, 65, 143-150. [CrossRef]

7. Saaristo, M.; Craft, J.A.; Lehtonen, K.K.; Björk, H.; Lindström, K. Disruption of sexual selection in sand gobies (Pomatoschistus minutus) by $17 \alpha$-ethinyl estradiol, an endocrine disruptor. Horm. Behav. 2009, 55, 530-537. [CrossRef]

8. Kidd, K.A.; Blanchfield, P.J.; Mills, K.H.; Palace, V.P.; Evans, R.E.; Lazorchak, J.M.; Flick, R.W. Collapse of a fish population after exposure to a synthetic estrogen. Proc. Natl. Acad. Sci. USA 2007, 104, 8897-8901. [CrossRef]

9. Routledge, E.J.; Sheahan, D.; Desbrow, C.; Brighty, G.C.; Waldock, M.; Sumpter, J.P. Identification of Estrogenic Chemicals in STW Effluent. 2. In Vivo Responses in Trout and Roach. Environ. Sci. Technol. 1998, 32, 1559-1565. [CrossRef]

10. Denslow, N.D.; Chow, M.C.; Kroll, K.J.; Green, L. Vitellogenin as a Biomarker of Exposure for Estrogen or Estrogen Mimics. Ecotoxicology 1999, 8, 385-398. [CrossRef]

11. Folmar, L.C.; Hemmer, M.J.; Denslow, N.D.; Kroll, K.; Chen, J.; Cheek, A.; Richman, H.; Meredith, H.; Grau, E.G. A comparison of the estrogenic potencies of estradiol, ethynylestradiol, diethylstilbestrol, nonylphenol and methoxychlor in vivo and in vitro. Aquat. Toxicol. 2002, 60, 101-110. [CrossRef]

12. Coe, T.S.; Hamilton, P.B.; Hodgson, D.; Paull, G.C.; Stevens, J.R.; Sumner, K.; Tyler, C.R. An Environmental Estrogen Alters Reproductive Hierarchies, Disrupting Sexual Selection in Group-Spawning Fish. Environ. Sci. Technol. 2008, 42, 5020-5025. [CrossRef] [PubMed]

13. Martinović, D.; Hogarth, W.T.; Jones, R.E.; Sorensen, P.W. Environmental estrogens suppress hormones, behavior, and reproductive fitness in male fathead minnows. Environ. Toxicol. Chem. 2007, 26, 271-278. [CrossRef]

14. Clotfelter, E.D.; Bell, A.M.; Levering, K.R. The role of animal behavior in the study of endocrine-disrupting chemicals. Anim. Behav. 2004, 68, 665-676. [CrossRef]

15. Söffker, M.; Tyler, C.R. Endocrine disrupting chemicals and sexual behaviors in fish-A critical review on effects and possible consequences. Crit. Rev. Toxicol. 2012, 42, 653-668. [CrossRef] [PubMed]

16. Chen, T.-H.; Chou, S.-M.; Tang, C.-H.; Chen, C.-Y.; Meng, P.-J.; Ko, F.-C.; Cheng, J.-O. Endocrine disrupting effects of domestic wastewater on reproduction, sexual behavior, and gene expression in the brackish medaka Oryzias melastigma. Chemosphere 2016, 150, 566-575. [CrossRef]

17. Dammann, A.; Shappell, N.; Bartell, S.; Schoenfuss, H. Comparing biological effects and potencies of estrone and $17 \beta$-estradiol in mature fathead minnows, Pimephales promelas. Aquat. Toxicol. 2011, 105, 559-568. [CrossRef] [PubMed]

18. Routledge, E.J.; Sumpter, J.P. Estrogenic activity of surfactants and some of their degradation products assessed using a recombinant yeast screen. Environ. Toxicol. Chem. 1996, 15, 241-248. [CrossRef] 
19. Gavrilescu, M.; Demnerová, K.; Aamand, J.; Agathos, S.; Fava, F. Emerging pollutants in the environment: Present and future challenges in biomonitoring, ecological risks and bioremediation. New Biotechnol. 2015, 32, 147-156. [CrossRef]

20. Kolpin, D.W.; Furlong, E.T.; Meyer, M.T.; Thurman, E.M.; Zaugg, S.D.; Barber, L.B.; Buxton, H.T. Pharmaceuticals, hormones, and other organic wastewater contaminants in US streams, 1999-2000: A national reconnaissance. Environ. Sci. Technol. 2002, 36, 1202-1211. [CrossRef]

21. Tyler, C.R.; van Aerle, R.; Hutchinson, T.H.; Maddix, S.; Trip, H. An in vivo testing system for endocrine disruptors in fish early life stages using induction of vitellogenin. Environ. Toxicol. Chem. 1999, 18, 337-347. [CrossRef]

22. Bartell, S.E.; Schoenfuss, H.L. Affinity and Matrix Effects in Measuring Fish Plasma Vitellogenin Using Immunosorbent Assays: Considerations for Aquatic Toxicologists. Isrn Toxicol. 2012, 2012, 1-8. [CrossRef] [PubMed]

23. Yost, E.E.; Pow, C.L.; Hawkins, M.B.; Kullman, S.W. Bridging the Gap from Screening Assays to Estrogenic Effects in Fish: Potential Roles of Multiple Estrogen Receptor Subtypes. Environ. Sci. Technol. 2014, 48, 5211-5219. [CrossRef]

24. Salierno, J.D.; Kane, A.S. $17 \alpha$-ethinylestradiol alters reproductive behaviors, circulating hormones, and sexual morphology in male fathead minnows (Pimephales promelas). Environ. Toxicol. Chem. 2009, 28, 953-961. [CrossRef] [PubMed]

25. Bell, A.M. Effects of an endocrine disrupter on courtship and aggressive behavior of male three-spined stickleback (Gasterosteus aculeatus). Anim. Behav. 2001, 62, 775-780. [CrossRef]

26. Filby, A.L.; Paull, G.C.; Searle, F.; Ortiz-Zarragoitia, M.; Tyler, C.R. Environmental Estrogen-Induced Alterations of Male Aggression and Dominance Hierarchies in Fish: A Mechanistic Analysis. Environ. Sci. Technol. 2012, 46, 3472-3479. [CrossRef]

27. Reese, G.A.; Romig, L.E.; Rockwell, S.L.; Travis, I.; Bartholomew, T.I.; Lipe, A.J. Saucon Creek TMDL Alternative report. Lehigh Valley Planning Commission. 2011. Available online: http:/ /www.lvpc.org/pdf/sauconCreekTMDLAlternativesReport.pdf (accessed on 22 July 2016).

28. Upper Saucon Township Water and Sewer Department Website. Available online: http://www.uppersaucon.org/townshipgovernment/water-and-sewer-department/ (accessed on 22 February 2016).

29. Colosi, J.C.; Kney, A.D. A yeast estrogen screen without extraction provides fast, reliable measures of estrogenic activity. Environ. Toxicol. Chem. 2011, 30, 2261-2269. [CrossRef] 